\title{
The exercise of interprofessionality and intersetoriality as an art of caring: innovations and challenges ${ }^{a}$
}

\author{
O exercício da interprofissionalidade e da intersetorialidade como arte de cuidar: inovações e desafios \\ El ejercicio de interprofesionalidad y intersectorialidad como arte de cuidar: innovaciones y desafíos
}

\author{
Camila Luana Oliveira Reuter ${ }^{1}$ \\ Vilma Constancia Fioravante dos Santos ${ }^{1}$ \\ Adriana Roese $\operatorname{Ramos}^{1}$ (D) \\ 1. Universidade Federal do Rio Grande do Sul. \\ Porto Alegre, RS, Brasil.
}

\begin{abstract}
Objectives: To analyze the innovations and challenges pointed out by the coordinators of basic care for the interprofessional and intersectoral exercise, and the importance of these practices as a potentiator of Nursing care and teaching in Primary Health Care. Methods: An exploratory study with a qualitative approach was carried out in a Rio Grande do Sul Health Region. Semistructured interviews were carried out with the Basic Attention Coordination of the Cities of the empirical area, between 2014 and 2015, with thematic content analysis. Results: The primary care coordinators highlight the effectiveness of interprofessional and intersectoral actions, but claim that there are still several obstacles for these actions to become routine. These professionals seek alternatives to modify the reality found, but not all have results. Conclusion: Intersectoriality and interprofessionality make it possible to carry out holistic and integral health actions, optimizing Nursing care practices.
\end{abstract}

Keywords: Interprofessional Relations; Intersectoral Collaboration; Health Communication; Primary Health Care; Public Health Nursing.

\section{Resumo}

Objetivos: Analisar as inovações e os desafios apontados pelas coordenadoras da atenção básica para o exercício interprofissional e intersetorial, e a importância dessas práticas como potencializadoras do cuidar e do ensinar a cuidar em Enfermagem, no âmbito da Atenção Primária em Saúde. Métodos: Estudo exploratório com abordagem qualitativa, realizado em uma Região de Saúde do Rio Grande do Sul. Foram realizadas entrevistas semiestruturadas junto às Coordenações de Atenção Básica dos Municípios da área empírica, entre 2014 e 2015, com análise de conteúdo temática. Resultados: Os coordenadores da atenção básica destacam a efetividade de ações interprofissionais e intersetoriais, mas afirmam que ainda há diversos entraves para que estas ações se tornem rotineiras. Esses profissionais da gestão buscam alternativas para modificar a realidade encontrada, mas nem todas possuem resultados. Conclusão: A intersetorialidade e interprofissionalidade possibilitam a realização de ações em saúde de cunho integral e holístico, otimizando as práticas de Enfermagem.

Palavras-chave: Relações Interprofissionais; Colaboração Intersetorial; Comunicação em Saúde; Atenção Primária à Saúde; Enfermagem em Saúde Pública.

\section{REsumen}

Objetivos: Analizar las innovaciones y los desafíos señalados por los coordinadores de la atención básica para el ejercicio interprofesional e intersectorial, y la importancia de estas prácticas como potencializadoras del cuidar y del enseñar a cuidar en Enfermería, en el ámbito de la Atención Primaria en Salud. Métodos: Estudio exploratorio con enfoque cualitativo, realizado en una Región de Salud de Rio Grande do Sul. Se realizaron entrevistas semiestructuradas junto a las Coordinaciones de Atención Básica de los Municipios del área empírica, entre 2014 y 2015, con análisis de contenido temático. Resultados: Los coordinadores de la atención básica destacan la efectividad de acciones interprofesionales e intersectoriales, pero afirman que todavía hay diversos obstáculos para que estas acciones se vuelvan rutinarias. Estos profesionales buscan alternativas para modificar la realidad encontrada, pero no todas tienen resultados. Conclusión: La intersectorialidad e interprofesionalidad posibilitan la realización de acciones en salud de cuño integral y holístico, optimizando las prácticas del cuidar en Enfermería.

Palabras clave: Relaciones Interprofesionales; Colaboración Intersectorial; Comunicación en Salud; Atención Primaria de Salud; Enfermería en Salud Pública.
Corresponding author:

Adriana Roese Ramos.

E-mail: adiroese@gmail.com

Submitted on $01 / 07 / 2018$.

Accepted on 08/03/2018.

DOI: 10.1590/2177-9465-EAN-2017-0441 


\section{INTRODUCTION}

Nursing is increasingly expanding its scope of health care for individuals and groups, both nationally and internationally. This makes the interest of a leader to be decisive and proactive in identifying the care needs of the population, as well as in the promotion and protection of life in its various dimensions. ${ }^{1,2}$

The field of Collective Health is permeated by the health care promoted by Nursing, in an interdisciplinary and communicative way with different social sectors, ${ }^{1}$ being undeniable the role that the nurse holds in identifying and intervening the population's health needs, through interactive practices and care integrators focused on education, health promotion and protection. ${ }^{1,3}$

In Brazil, the responsibilities of Nursing Professionals in Primary Health Care $(\mathrm{PHC})$ received important contributions in both care and management fields, with the approval of the National Policy, ${ }^{4}$ which establishes guidelines for the organization of this health care model. This is a relevant institutional benchmark, since it corroborates nine specific managerial attributions for the work of Nurses in $\mathrm{PHC}$, which already has regulated the actions of managing, coordinating, planning and directing services and actions in which Nursing is working. ${ }^{5}$ The range of actions developed by nurses in $\mathrm{PHC}$, evidenced in national studies ${ }^{6,7}$ and international, ${ }^{3}$ are those of care, management and educational and involve social control, a fact that comes to the foregoing considering the current legislation.

The performance of nurses in $\mathrm{PHC}$ contributes to the diversification and consolidation of Nursing activities and to the expansion of the body of knowledge of this profession. ${ }^{2}$ These professionals have a double journey of actions directed at the individual and the collective, which correspond to the production of Nursing care and management of therapeutic projects; management of the Nursing team and the health service for providing care. ${ }^{8}$

The professional involvement with management actions within PHC teams occupies nurses in an important way, so that they can distance them from the closest care with users, since the management of health services involves bureaucratic activities for their administration. This specificity demands more participatory forms of management with the development of skills and competences that can give subsidies to nurses delegating functions, for example. ${ }^{9}$

Thus, Nursing care in PHC will encompass actions that go from technical procedures, such as those related to the core of professional knowledge (interaction between users and workers) to broader elements such as care planning, care coordination and evaluation of actions developed by the team. ${ }^{10}$

Management performance by nurses is a form of care that should be prioritized as well as the care practice, considering that management processes must be carried out in a way interconnected to the health needs of the community, seeking to introduce the practices of care and attention focuses. ${ }^{7}$
On the other hand, the diversity of activities, already presented, leads to work overload that, consequently, causes nurses to distance themselves from strictly care activities, which ultimately directs their actions and attributions to the performance of management and administrative activities. ${ }^{7}$

In the reality of $\mathrm{PHC}$, most of time, nurses perform activities that are not only related to Nursing and Community Health Agents (CHA) team. Conducting participatory and shared management (co-management) is a way to alleviate the accumulation of nurses' activities and encourage the co-responsibility of all staff in providing care. ${ }^{9}$ In view of this, it is important to consider, within the scope of PHC, interprofessional work, since it is integrated with intersectoral work, providing the integration and implementation of broad work carried out in this context.

Interprofessional action is an articulated form of teamwork, that allows the action of a collaborative and participative way among different professionals, who seek to offer care meeting the health needs of users, recognizing the complexity of the situation brought by them, as well as the context in which they are. ${ }^{11}$ This way of acting allows health actions to occur in an articulated and integrated manner, which tends to encourage co-responsibility and avoid duplication of care, waiting and unnecessary postponing; provides improvement in communication among professionals, as well as the recognition of contributions of each field of knowledge, ${ }^{12}$ resulting in greater resolution and quality of health services. ${ }^{12,13}$ Interprofessional teams must present some characteristics that allow them to carry out effective work, that act in an integrated way, allowing its effectiveness. These characteristics are: respect and trust, recognition of different professionals and interdependence to carry out various actions. The implementation of interprofessional work provides the integration and organization of health actions and favors the establishment of a network of care among the different levels of health care. ${ }^{14}$

For this network of care provided by interprofessional work to be holistic, it is necessary to consider intersectoral relations for health actions. Thinking in the context of health, intersectoriality encompasses the relationship between one or several parts of one health sector with one or several parts of another sector, acting on a common theme, to achieve more effective results, which the health sector, acting individually, would not achieve. ${ }^{15}$ By thinking of this concept in a broader sense, it can be understood as a complex political strategy in guaranteeing the right to health, which needs to overcome the fragmentation of enforcing policies and thus solve daily problems, articulating different sectors of municipal management. ${ }^{16}$

With this, it is possible to understand that intersectoriality allows and favors the strengthening of health care network through shared dialogues between institutions, government and people, allowing the elaboration of public policies that have beneficial impacts on the population's health. ${ }^{17}$ 
Looking at the numerous roles of the nurses in PHC, the change in the profile of the population and some actions and alternatives already recommended to offer an improvement of health services and actions, the present article has as its objective to analyze innovations and challenges pointed out by the coordinators of basic care for the interprofessional and intersectoral exercise, and the importance of these practices as enhancers of caring and teaching care in Nursing in Primary Health Care.

\section{METHODOLOGY}

This is a descriptive exploratory study with a qualitative approach, ${ }^{18}$ carried out in Health Region 10 of Rio Grande do Sul State, which is composed of six municipalities: Alvorada, Cachoeirinha, Glorinha, Gravataí, Porto Alegre and Viamão. The choice of the health region occurred due to the challenges imposed by the organization of the health care network, especially regarding the chronic illness in the metropolitan region, thus adding the metropolis Porto Alegre and large municipalities.

The participants of this study were Primary Care Coordinators (PCC) of the municipalities mentioned above. In these, this management position was assumed, for the most part, by nurses. A total of nine professionals were interviewed, including seven nurses, one nurse and one doctor. In one of the municipalities there were two PCC, and in two others, besides the coordination of Primary Care, two other Coordinators of the Health Department also participated.

Interviews were conducted between the second half of 2014 and the first half of 2015. They were held in a day and place previously agreed with the coordinators, via telephone and/or e-mail. The questions dealt with organization and management of NCDs in PHC and strategies adopted by Primary Care Coordinators to face the daily challenges of the organization of services.

As for the organization of data, the same procedures adopted in previous research were followed ${ }^{19}$ so that it was possible to carry out the content analysis. ${ }^{18}$ The thematic categorization, with the aid of NVivo 9 software, was conducted in three stages: pre-analysis, exploitation of material and treatment of results obtained, and interpretation. ${ }^{18}$ The interviewees received the following codification: IPCC - interviews with managers, from one (1) to nine (9). Considering the proximity of management activities, the two other co-ordinations of the Health Department with the same codification remained, since they were included at the request of the then PCC.

Regarding bioethical considerations, as in another publication, ${ }^{19}$ the guidelines recommended by the National Health Council (Conselho Nacional de Saúde) were respected. ${ }^{20}$ This study was approved by the Research Committee of the Escola de Enfermagem da Universidade Federal do Rio Grande do Sul
(UFRGS), by the Ethics Committees of UFRGS and the Municipal Health Department (Secretaria Municipal de Saúde) of Porto Alegre City, under reports, No. 708.357/2014 and 885.916/2014, respectively.

\section{RESULTS}

Empirical data showed that, when it comes to the organization of permanent education, not all Municipalities have their Municipal Nuclei of Collective Health Education (Núcleos Municipais de Educação em Saúde Coletiva - NUMESC) formalized or acting in partnership with teams, which may make it difficult for professionals to keep updated. NUMESC is an innovative and empowering space for health practices, involving the perspective of permanent education that promotes the interlocution of different knowledge and actions, putting knowledge in motion and articulating it in daily life. Its constitution and consolidation are still a challenge to municipalities and teams, but an important space of interprofessional exercise in $\mathrm{PHC}$ and insertion of Nursing.

[...] but now we are implementing it, trying to organize ourselves better to adopt NUMESC, in a formalized way, within an organized team responsible for it, making organizations acknowledge what are the demands and then we will know what is reaching the top so that we can provide an answer for that (IPCC 9).

Another factor that runs through this situation is the lack of availability of professionals and flexibility of the institutional organization of services so that there is involvement with the interprofessional and intersectoral actions of permanent or continuous education, promoted by the Municipalities.

[...] Accountability is important, there were always had skills and such, but they were very sporadic and cannot work program coordination without working all the time with education. And I started to realize that people, besides spending a lot of time, let's say, doing nothing, without any kind of qualification, updating, they had not the least willingness to do. And the first skills I set up here had half a dozen people! (IPCC 9).

One form of work that was pointed out is the realization of preventive and long-term actions, advocated by policies, in which it is idealized that they be carried out by interprofessional teams, which occur within health services.

Here, we work a little differently. Policies think, and we execute a little more, have long-term actions, such as the 
chronic diseases outpatient clinic, specialized center and specific programs that enable the network for actions... And there are actions for prevention, that we wanted the matrix of these actions, and to discuss cases with family doctors, nurses, agents... [...] (IPCC 7).

Coordinators, mostly nurses, emphasize the need to carry out interprofessional and intersectoral work, considering the multiple facets of caring and teaching care in Primary Health Care associated with social diversity and health problems presented by the population cared.

[...] it will not be a specific action to resolve that issue. That transcends health, goes to other areas, such as social assistance, housing, employment. Often, a health action cannot reach all these points, so you must also assess the impact of this action [...] (IPCC 4).

[...] we cannot, nowadays, work alone. There are some things that demand help from social workers, other departments, so there must be a partnership (IPCC 1).

Even though municipalities consider it relevant to provide intersectoral care, one of the nurses coordinators has reported that there are still many obstacles and difficulties that make the process of trying to form an interprofessional team a challenge. This report demonstrates the potential of innovation that Nursing has in face of reality, especially regarding health care practices in PHC. Interprofessional and intersectoral articulation is not something new, but difficult to reach, because professions are still very much rooted at the knowledge of their field, and struggle to promote a true integration. Nursing is the area of health that problematizes, brings closer together different professionals and promotes possible dialogues that, in the speech of the interviewed nurse, appears as meticulous work.

[...] It is difficult everywhere, with some sectors is quite meticulous work. In general, it is a difficulty, it is a challenge factor [...] (IPCC 7).

PCC cite some alternatives created by the municipalities to overcome challenges found for the consolidation of an intersectoral system. They are management projects that work in a network, through scheduled meetings, involving several municipal and regional sectors to discuss new strategies of care, seeking ways to enhance these spaces of action.

[...] is a management proposal including the creation of committees of intersectoral public policies, new work, in which periodic monthly meetings occur, divided by thematic axes. Yes, there is an attempt, but there are no results yet [...] (IPCC 9).

$[. .$.$] they form a network meeting. They try to form, to do,$ to format... [...] (IPCC 7).

There are regional meetings, [...] the 'Rede Chama'. It is a network composed of all the bodies of the municipality, so it has this regional articulation[...] (IPCC 4).

One of the municipalities associated the fact that it has a smaller territorial extension as a facilitator to realize intersectoral network, due to the fact that it believes communication between services occurs in a more facilitated and effective way.

Communication is very good [...] (IPCC 6).

[...] A small place, this intersectoriality becomes easier (IPCC 5).

It was unanimous among coordinators, when dealing with intersectoriality, to report the actions developed jointly with the Municipal Departments of Education for Health in School Program (Secretarias Municipais de Educação para o Programa Saúde na Escola - PSE). They consider it a strong tool of action in health and education, which also assists in raising awareness of the whole community, as well as enhancing care practices and teaching care for children, adolescents and teachers.

We have PSE, which develops prevention actions, education with teachers. In this group of PSE we have worked education and with other departments, forming a management group. They have curative and educational actions. This program has the strength to leave Brazil and interact as a whole [...] (IPCC 7).

[...] we have worked hard with the Department of Education, using the spaces of schools, kitchens of schools. Some units do this and there, the nutritionists perform a very interesting job, especially in the PSE (IPCC 8).

One of the coordinators interviewed highlighted how effective and resolutive Nursing care becomes, especially in-home visits, when in partnership with different professionals and sectors. This is an important tool for practices that consolidate interprofessionality and intersectoriality in caring for users.

[...] when there is some health visit to pay, a nurse always goes together. We make this visit together and it works very well. When you must forward, we make the visit and a referral together (IPCC 5). 


\section{DISCUSSION}

Given the wide scope of tasks developed by nurses in $\mathrm{PHC}$, it is possible to highlight the supervision and orientation of the Nursing team. This activity can be aided by the permanent education of professionals. The Permanent Education in Health $(\mathrm{PEH})$ is a pedagogical political strategy established as National Policy through Ordinance $\mathrm{n}$ - 198/2004, being reformulated by

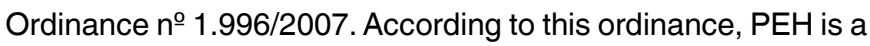
learning-work relationship, which occurs in the daily life of health services, where learning and teaching are incorporated into work processes, ${ }^{8}$ considering the knowledge and experiences already experienced by professionals, through a problematizing methodology based on the problems faced, aiming at the health needs of individuals and populations. ${ }^{21}$

Theoretically, $\mathrm{PEH}$ is based on four principles: autonomy, citizenship, actors' subjectivity and learning in, by and for practice. ${ }^{22}$ This reasoning is due to two objectives, that $\mathrm{PEH}$ seeks to achieve meaningful learning and the possibility of transforming professional practices. $^{21}$

With this in view, the introduction of $\mathrm{PEH}$ is relevant for the qualification of health care provided to population in accordance with the principles of the Unified Health System (SUS), favoring the articulation between teaching and service. ${ }^{23,24}$ The qualification of care occurs as a result of $\mathrm{PEH}$, allowing professionals to become more critical and empowered, able to initiate a process of recognition, negotiation and response, in a pertinent way, to the health needs of users and the population, allowing the approach of community professionals. ${ }^{25,26}$

Although there are several positive factors for the transformation and qualification of health actions and services associated with the introduction of $\mathrm{PEH}$, there are still many limitations to introduce this process. ${ }^{24}$ The lack of Municipal Centers of Education in Collective Health (Núcleos Municipais de Educação em Saúde Coletiva), as mentioned by the PCC, is an important challenge for the Municipalities, considering that these spaces have the potential to promote debates that will foster the articulation of different actors around the resolution of problems of managerial action of Nursing professionals.

This is just one of the obstacles pointed out by the PCC to carry out $\mathrm{PEH}$. The interviewees still report that difficulties involve the lack of availability and interest of professionals, besides the flexibility of health services in relation to the involvement in educational actions. In a study, ${ }^{23}$ it was found that PEH actions developed by nurses had the flexibility of health services as a potent strategy for their establishment. Even with strategies that benefited the accomplishment of educational actions, they still found as limitations the resistance and lack of commitment of professionals in relation to the educative process. There are still several obstacles that permeate the introduction of $\mathrm{PEH}$, which makes it difficult to modify professional practice in the complex context of health work. It is necessary to encourage the innovation of new methods, thinking about the quality of management and care. ${ }^{24}$

Due to the increasing complexity and cost of services associated with the needs and expectations of users and workers, especially in PHC, there is a greater possibility of confusion, duplication and inefficiency in the health actions offered. Because of this complexity, there is a need for interaction of health professionals, to think about the effectiveness of services provided. ${ }^{13}$ Given this, it is necessary to ponder about alternatives and new methodologies that improve and reorder the organization of health services.

One of the working methods pointed out by the PCC, which can enhance health actions, is the formation of interprofessional teams articulated to intersectoral attention. Thus, they affirm that health care can be offered in a holistic way to users, considering the environment in which they are inserted and the difficulties they face.

Interprofessional action requires teamwork, participatory and collaborative initiatives between different professionals, who will act in an articulated way, strengthening the centrality in users, aiming at the care of their health needs and life context. ${ }^{11,12}$ Interprofessional work has been shown to be one of the best methods of action in health to face the various challenges present in this environment. ${ }^{27}$ This allows for an increased resolution of services provided and qualifies health care. ${ }^{11}$

From this perspective, it can be affirmed that interprofessionality articulates different professionals, so it is not possible to discard the intersectoriality of this reality, since professionals, even acting in teams, belong to different sectors. The intersectoriality is related to one or several parts of the health sector linked to the part (s) of other sector (s), to achieve more effective health outcomes, through professional performance inside and outside one's sector, ensuring a network of protection to users. ${ }^{28}$

However, the implementation of these work organization practices to provide excellence care does not occur easily. One of the interviewees pointed out that there are several challenges for accomplishing that, and said these difficulties have different amplitudes, depending on the service to be contacted. In a study conducted, ${ }^{29}$ it was found that during work of the interprofessional team there are some conflicting situations, which hamper the interaction between different professionals. The main situations encountered were disagreement regarding the priority of care of patients, arrival of new professionals in the team, lack of trust, recognition of work of others and collaboration in patient care. ${ }^{8}$ In another study, ${ }^{30}$ conducted with health managers, it was recognized that there are advances in intersectoral actions, but it is affirmed that intersectoriality is restricted to the "required" 
in federal induction programs and policies, being limited to partnerships, referrals (fragile agreements) and share some resources, materials and professionals.

In view of the above, actions are required to modify the reality found, to facilitate the introduction and future execution of interprofessional and intersectoral actions. The PCC interviewed report that municipalities create methodologies to overcome challenges. The coordinations are based on management projects that operate in a network, through scheduled and periodic meetings, involving several municipal and regional sectors to discuss new strategies of care. This space favors articulation and communication, promoting their effectiveness, and makes the accomplishment of preventive and curative actions in health easier.

These considerations are also pertinent for the question of lack of institutional flexibility in favor of actions that can build collective bodies for professional training in service, which may be further reducing interprofessional actions in PHC teams, health services and weakening communication among professionals. ${ }^{12,13}$

It is understood that communication is an inherent action of teamwork, being transversal to other elements needed for the accomplishment of teamwork. This is because it allows the construction of other essential elements such as trust, bonding, mutual respect, recognition of each other's work and collaboration, necessary for the interprofessional team. ${ }^{29}$ However, communication spaces between services are scarce, making it difficult to carry out joint planning. Therefore, programs, collegial bodies and management techniques, such as forums, committees, chambers and territorial intersectorial nuclei, are needed to promote the joint elaboration of actions, policies, goals and definition of roles among professionals from different services, making the union and exchange of different knowledge possible, which belong to each professional, ${ }^{28}$ an alternative that meets what interviewees performed.

In a study, ${ }^{30}$ it was noted that the main articulations conducted between sectors occurred with social assistance, health and education, in which the majority of actions performed involved monitoring compliance with conditionalities for the maintenance of program benefits. Related to the educationhealth relationship, a study ${ }^{31}$ revealed that this relationship is permeated by tensions in planning and introducing actions, and there is evidence of punctual actions and referrals of situations considered as problems. The situation is contrary to that evidenced by the PCC of this study, since all reported successful health actions when in partnership with the education sector.

The multiplicity of actions that make up work carried out in PHC shows the complexity of nurses' work, who act as coordinators in this level of care, demonstrating that intersectoriality and interprofessionality are intrinsic elements to integral health care. Therefore, understanding that intersectorality is one of the components that strengthens health management ${ }^{16}$ is valid to endorse the understanding expressed by the coordinating nurses participating in the study. In addition, it is necessary to reflect that intersectoriality refers to a complementary role among those involved, in an interdependent manner and with horizontal relationships, in which health care involves all stakeholders, both professionals and citizens. ${ }^{16}$

Considering this scenario, it is imperative that nurses work in these environments, considering their potential of articulating care performed in partnership with other areas and professional categories, prioritizing work and team, with the objective of effective care centered on the patient. ${ }^{29}$ The interviewees of the study show this fact and report how beneficial and effective the health actions become when carried out interprofessionally and intersectorially.

\section{CONCLUSIONS}

Municipal management still encounters numerous difficulties in complying with SUS principles, given the difficult task of implementing interprofessionality and intersectoriality, which sometimes does not provide integral attention to users.

In this context, considering the roles that nurses have in $\mathrm{PEH}$ and their potential to offer effective and resolutive care, it is necessary to articulate alternatives and working methods that can modify this reality, facilitating the implementation of interprofessional and intersectoral health actions.

The work practice of some municipalities with the use of network management projects to carry out interprofessional and intersectoral work, in addition to the NUMESC implementation perspective, collaborate to rethink the reality of health work. From this perspective, it is believed that Interprofessional Education can act as an innovative methodology of teaching and care, which will produce good results and facilitate the accomplishment of health actions that are interprofessional and intersectoral, holistic and integral, and, in this way, optimize and qualify Nursing practices and their articulation with other professionals and sectors.

\section{REFERENCES}

1. Backes DS, Backes MS, Erdmann AL, Büscher A. O papel profissional do enfermeiro no Sistema Único de Saúde: da saúde comunitária à estratégia de saúde da família. Ciênc Saúde Coletiva [Internet]. 2012; [cited 2017 Dec 1]; 17(1):223-30. Available from: http://www.scielo.br/scielo.php?script=sci_arttext\&pid=S1413$81232012000100024 \&$ Ing $=\mathrm{e}$

2. Toso BRGO, Filippon J, Giovanella L. Atuação do enfermeiro na Atenção Primária no Serviço Nacional de Saúde da Inglaterra. Rev Bras Enferm [Internet]. 2016 Jan/Feb; [cited 2017 Dec 5]; 69(1):16977. Available from: https://www.arca.fiocruz.br/bitstream/icict/16445/2/ Atua\%C3\%A7\%C3\%A3oEnfermeiro.pdf 
3. Halcomb E, Stephens M, Bryce J, Foley E, Ashley C. Nursing competency standards in primary health care: an integrative review. J Clin Nurs [Internet]. 2016; [cited 2017 Dec 23]; 25(9/10):1193-205. Available from: http://ro.uow.edu.au/cgi/viewcontent.cgi?article $=4720$ \&context=smhpapers

4. Ministério da Saúde (BR). Portaria № 2.436, de 21 de setembro de 2017. Aprova a Política Nacional de Atenção Básica, estabelecendo a revisão de diretrizes para a organização da Atenção Básica, no âmbito do Sistema Único de Saúde (SUS). [Internet]. 2017; [cited 2017 Dec 5]. Available from: http://www.foa.unesp.br/home/pos/ppgops/ portaria-n-2436.pdf

5. Governo Federal (BR). Lei №. 7.498, de 25 de junho de 1986. Dispõe sobre a Regulamentação do Exercício da Enfermagem e dá outras providências. Brasília (DF): Governo Federal; 1986. [Internet]. 1986 [cited 2017 Dec 3]. Available from: http://www.planalto.gov.br/ccivil_03/ leis/l7498.htm

6. Farah BF, Dutra HS, Ramos ACTM, Friedrich DBC. Nurses' perceptions on nursing supervision in Primary Health Care. Rev Rene [Internet]. 2016 Nov/Dec; [cited 2017 Dec 4]; 17(6):804-11. Available from: http:// periodicos.ufc.br/rene/article/view/6501/4737

7. Galavote HS, Zandonade E, Garcia ACP, Freitas PSS, Seidl H, Contarato $\mathrm{PC}$, et al. $\mathrm{O}$ trabalho do enfermeiro na atenção primária à saúde. Esc Anna Nery [Internet]. 2016 Jan/Mar; [cited 2017 Dec 4]; 20(1):90-8. Available from: http://www.redalyc.org/html/1277/1277443318013/

8. Matumoto S, Fortuna CM, Kawata LS, Mishima SM, Pereira MJB. A prática clínica do enfermeiro na atenção básica: um processo em construção. Rev Latino Am Enferm [Internet]. 2011 Jan/Feb; [cited 2017 Dec 9]; 19(1):[8 telas]. Available from: http://www.scielo.br/pdf/ rlae/v19n1/pt_17.pdf

9. Jonas LT, Rodrigues HC, Resck ZMR. A função gerencial do enfermeiro na Estratégia Saúde da Família: limites e possibilidade. Rev APS [Internet].2011 Jan/Mar; [cited 2017 Dec 9]; 14(1):28-38. Available from: https://aps.ufjf.emnuvens.com.br/aps/article/view/977/443

10. Santos JLG, Pestana AL, Guerrero P, Meirelles BSH, Erdmann AL. Práticas de enfermeiros na gerência do cuidado em enfermagem e saúde: revisão integrativa. Rev Bras Enferm [Internet]. 2013 Mar/Apr; [cited 2017 Dec 16]; 66(2):257-63. Available from: http://www.redalyc. org/html/2670/267028666016/

11. Silva JAM, Peduzzi M, Orchard C, Leonello VM. Educação interprofissional e prática colaborativa na Atenção Primária à Saúde. Rev Esc Enferm USP [Internet]. 2015 Dec; [cited 2017 Dec 15]; 49(spe2):16-24. Available from: http://www.scielo.br/scielo. php?script=sci_arttext\&pid=S0080-62342015000800016\&lng=pt\&nr $\mathrm{m}=\mathrm{iso}$

12. Peduzzi M, Norman IJ, Germani ACCG, Silva JAM, Souza GC. Educação interprofissional: formação de profissionais de saúde para o trabalho em equipe com foco nos usuários. Rev Esc Enferm USP [Internet]. 2013 Aug; [cited 2017 Dec 3]; 47(4):977-83. Available from: http://www.scielo. br/scielo.php?script=sci_arttext\&pid=S0080-62342013000400977\&ln $\mathrm{g}=$ pt\&nrm=iso

13. Matuda CG, Aguiar DML, Frazão P. Cooperação interprofissional e a Reforma Sanitária no Brasil: implicações para o modelo de atenção à saúde. Saude Soc [Internet]. 2013 Jan/Mar; [cited 2017 Dec 13]; 22(1):173-86. Available from: http://www.scielo.br/scielo. php?script=sci_arttext\&pid=S0104-12902013000100016\&lng=pt\&nr $m=$ iso

14. D'Amour D, Goulet L, Labadie JF, Martín-Rodriguez LS, Pineault R. A model and typology of collaboration between professional in healthcare organization. BMC Health Serv Res [Internet]. 2008 Sep; [cited 2017 Dec 16]; 8:188[15 telas]. Available from: https://bmchealthservres. biomedcentral.com/articles/10.1186/1472-6963-8-188

15. Teixeira CF, Paim JS. Planejamento e programação de ações intersetoriais para a promoção da saúde e da qualidade de vida. Rev Adm Pública [Internet]. 2000 Nov/Dec; [cited 2017 Dec 14]; 34(6):63-80. Available from: http://bibliotecadigital.fgv.br/ojs/index.php/rap/article/ view/6348/4933
16. Ministério da Saúde (BR). Conselho Nacional de Secretarias Municipais de Saúde. O SUS de A a Z: Garantindo Saúde nos Municípios. $3^{\text {a }}$ ed. Brasília (DF): Ministério da Saúde; 2009. Available from: http:// bvsms.saude.gov.br/bvs/publicacoes/sus_az_garantindo_saude_ municipios_3ed_p1.pdf

17. Olschowsky A, Wetzel C, Schneider JF, Pinho LB, Camatta MW. Avaliação das parcerias intersetoriais em saúde mental na estratégia saúde da família. Texto Contexto Enferm (Florianópolis) [Internet]. 2014 Jul/Sep; [cited 2017 Dec 3]; 23(3):591-9. Available from: http://www. scielo.br/pdf/tce/v23n3/pt_0104-0707-tce-23-03-00591.pdf

18. Minayo MCS. O desafio do conhecimento: pesquisa qualitativa em saúde. 12a ed. São Paulo: Hucitec; 2010.

19. Reuter CLO, Santos VCF, Bottega CG, Roese A. Monitoring practices in municipal healthcare management and their interface with nursing. Rev Gaúcha Enferm [Internet]. 2016; [cited 2018 Jul 26]; 37(spe):e2016-19. Available from: http://www.scielo.br/pdf/rgenf/v37nspe/en_0102-6933rgenf-1983-14472016esp2016-0019.pdf

20. Ministério da Saúde (BR). Conselho Nacional de Saúde. Resolução № 466, de 12 de dezembro de 2012. Diretrizes e normas regulamentadoras de pesquisas envolvendo seres humanos. Brasília (DF): Ministério da Saúde; 2012. Available from: http://bvsms.saude.gov.br/bvs/saudelegis/ cns/2013/res0466_12_12_2012.html

21. Ministério da Saúde (BR). Portaria GM/MS № 1.996, de 20 de agosto de 2007. Dispõe sobre as diretrizes para a implementação da Política Nacional de Educação Permanente em Saúde e dá outras providências. Brasília (DF): Ministério da Saúde; 2007. Available from: http://bvsms. saude.gov.br/bvs/saudelegis/gm/2007/prt1996_20_08_2007.html

22. Lima LPS, Ribeiro MRR. A competência para Educação Permanente em Saúde: percepções de coordenadores de graduações da saúde. Physis [Internet]. 2016 Apr/Jun; [cited 2017 Dec 23]; 26(2):483-501. Available from: http://www.scielo.br/scielo.php?script=sci_arttext\&pid=S010373312016000200483\&lng=pt\&nrm=iso

23. Lavich CRP, Terra MG, Mello AL, Mello CT. Ações de educação permanente dos enfermeiros facilitadores de um núcleo de educação em enfermagem. Rev Gaúcha Enferm [Internet]. 2017 Apr; [cited 2017 Dec 21]; 38(1):e62261. Available from: http://www.scielo.br/scielo. php?script=sci_arttext\&pid=S1983-14472017000100403\&lng=pt\&nr $\mathrm{m}=$ iso

24. Sena RR, Grillo MJC, Pereira A, Belga SMMF, França BD, Freitas CP. Educação permanente nos serviços de saúde: atividades educativas desenvolvidas no estado de Minas Gerais, Brasil. Rev Gaúcha Enferm [Internet]. 2017 Jul; [cited 2017 Dec 21]; 38(2):e64031. Available from: http://www.scielo.br/scielo.php?script=sci_arttext\&pid=S198314472017000200407\&lng=pt\&nrm=iso

25. Paschoal AS, Mantovani MF, Méier MJ. Percepção da educação permanente, continuada e em serviço para enfermeiros de um hospital de ensino. Rev Esc Enferm USP [Internet]. 2007 Sep; [cited 2017 Dec 21]; 41(3):478-84. Available from: http://www.scielo.br/scielo. php?script=sci_arttext\&pid=S0080-62342007000300019\&Ing=pt\&nr $\mathrm{m}=\mathrm{iso}$

26. Peduzzi M, Del Guerra DA, Braga CP, Lucena FS, Silva JCM. Atividades educativas de trabalhadores na atenção primária: concepções de educação permanente e de educação continuada em saúde presentes no cotidiano de Unidades Básicas de Saúde em São Paulo. Interface (Botucatu) [Internet]. 2009 Jul/Sep; [cited 2017 Dec 21]; 13(30):12134. Available from: http://www.scielo.br/scielo.php?script=sci_ arttext\&pid=S1414-32832009000300011\&lng=pt\&nrm=iso

27. Farias DN, Ribeiro KSQS, Anjos UU, Brito GEG. Interdisciplinaridade e interprofissionalidade na Estratégia Saúde da Família. Trab Educ Saúde [Internet]. 2017 Dec; [cited 2017 Dec 20]; 16(1):141-62. Available from: http://www.scielo.br/scielo.php?script=sci_arttext\&pid=S1981 $77462017005005106 \&$ Ing=pt\&tlng=pt 
28. Ferro LF, Silva EC, Zimmermann AB, Castanharo RC, Oliveira FRL. Interdisciplinaridade e intersetorialidade na Estratégia Saúde da Família e no Núcleo de Apoio à Saúde da Família: potencialidades e desafios. O Mundo da Saúde (São Paulo) [Internet]. 2014; [cited 2017 Dec 21]; 38(2):129-38. Available from: https://www.saocamilo-sp.br/ pdf/mundo_saude/155562/A01.pdf

29. Souza GC, Peduzzi M, Silva JAM, Carvalho BG. Trabalho em equipe de enfermagem: circunscrito à profissão ou colaboração interprofissional. Rev Esc Enferm USP [Internet]. 2016; [cited 2017 Dec 14]; 50(4):640-7. Available from: http://www.scielo.br/pdf/reeusp/v50n4/pt_0080-6234reeusp-50-04-0642.pdf
30. Silva KL, Sena RR, Belga SMMF, Silva PM, Rodrigues AT. Promoção da saúde: desafios revelados em práticas exitosas. Rev Saúde Pública [Internet]. 2014 Feb; [cited 2017 Dec 14]; 48(1):76-85. Available from: http://www.scielo.br/scielo.php?script=sci_arttext\&pid=S0034$89102014000100076 \&$ Ing $=$ pt\&nrm=iso

31. Silva KL, Sena RR, Akerman M, Belga SMM, Rodrigues AT. Intersetorialidade, determinantes socioambientais e promoção da saúde. Ciênc Saúde Coletiva [Internet]. 2014 Nov; [cited 2017 Dec 14]; 19(11):4361-70. Available from: http://www.scielo.br/scielo. php?script=sci_arttext\&pid=S1413-81232014001104361\&lng=pt\&nr $\mathrm{m}=$ iso

a This article is part of the research "Chronic Noncommunicable Diseases and Health Planning: Challenges of the Porto Alegre-RS Metropolitan Region", funded by the Rio Grande do Sul Research Support Foundation (Fapergs) in partnership with the Ministry of Health Health (MS), with the National Council for Scientific and Technological Development (CNPQ) of Brazil and the State Secretariat of Health of Rio Grande do Sul/SES-RS within the scope of the Research Program for SUS: shared health management, under call Fapergs/MS/CNPq/SESRS n. 002/2013. 